\title{
A NEW MEXICAN GENUS OF PLEUROCERATID正.
}

\author{
By Professor Henry A. Pilsbim. \\ Read 10th December, 1909.]
}

Awoxg the shells collected by Mr. A. A. Hinkley during his last journey to Mexico (January and February, 1909), were two species of the family Pleuroceratidx which cannot be referred to any of the known genera. Up to this time no member of this family has been recorded south-west of central Texas, where Goniobasis convalensis, Pilsbry, is found in the streams of Hass, Cornal, and Bexar counties.'

Lrrmasiorsis, n.gen.

Shell rarging from cylindric with conic spire to orate-turrite, similar in contour to Goniobasis or Lithasia, solid. Aperture ovate or piriform, rounded at the base; outer lip thin and acute; columella concave, broad; parietal wall corered with a heary callus, which is thickest near the posterior angle of the aperture. Operculum very shortly ovate, nearly circular, the nucleus at its lower fourth. Inside there is an oblong dull area of attachment along the columellar side, bounded by a raised border or brown cord; the rest of the inner face being glossy.
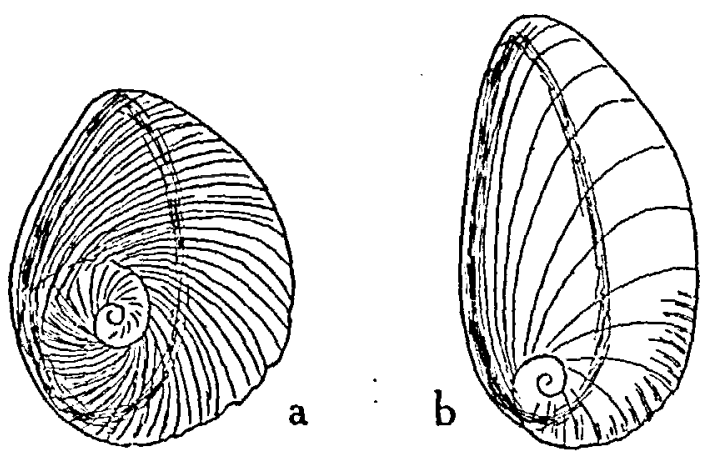

Frg. 1. a, Lithasiopsis Irinkleyi ; b, Lithasia oborata.

Radula similar to that of Anculosa. The central tooth is short and wide, with $3,1,3$ denticles, the body of the tooth smooth below the cusps. The admedian tooth has a rery broad, truncate inner cusp and two small outer ones. Its body projects at the Iower inner angle. The innei and outer lateral teeth or uncini hare five and ten denticles respectively. The shank of the inner uncinus is dilated towards its base.

Type.-L. Ininkleyi.

1 Pilsbry \& Fernis, Mollusea of the South-Western States, II : Proc. A. N. S. Philad., 1906, p. 167 . 
Shells of this genus have the hearily calloused inner lip of Lithasia, but differ from that genus by the operculum, which in Lithasia is oblong with almost basal nucleus (fig. 1 $b$, L. obovata, Say). Some forms of the heterogeneous group Goniobasis have a similar operculum, but they differ by the thin parietal callus. Lithasiopsis is not unlike Melanopsis in the calloused columella, but it differs in important features of the dentition. In dentition lithasiopsis stands nearest Anculosa, which it resembles in having the inner cusp of the admedian toath enormously dereloped.

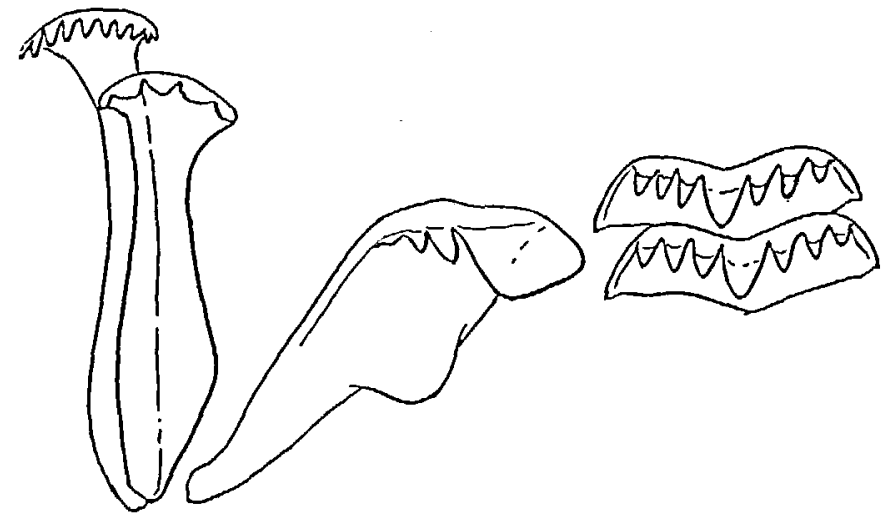

Fra. 2. Lithasiopsis Irinkleyi.

Lithasiopsis inhabits streams tributary to the Panuco River. This river system has one of the richest faunas of freshwater shells in Mexico. Mr. Hinkley's researches have brought to light a considerable number of Unionida; a fine group of Pachycheili, including sereral globose forms like Paludomus; species of Somatogyrus, Amnicola, Potamopyrgus, Cochliopa, Emmericia, Pterides, and Gundlachia, etc. Except the Lymnaidx most of the species are unknown elsewhere, but a few extend as far south as Vera Cruz, and some others north to the Rio Grande.

Lrrmasiopsis Hixkley, n.sp. Figs. 1a, 2, 3.

The shell is cylindric, or oval cylindric, with a short acute spire with concave outlines; solid, dull sellow or greenish-yellow. The first $1 \frac{1}{2}$ whorls are smooth, glossy, and conrex; the following $1 \frac{1}{2}$ to $2 \frac{1}{2}$ whorls dull, only slightly convex, showing a keel or thread above or in the suture below. In the typical form the following whorl has an acute median spiral thread. The penultimate and next earlier whorls bear three strong spirals, and these continue upon the last whorl, which has a group of spiral cords at the shoulder, is smooth and flat or concare in the middle, and has weak spiral cords on tho base. (In the smooth form the later whorls are without spiral sculpture, and it may be very weak or almost wanting on the spire.) 
The aperture usually exceeds lalf the total length, is orate or piriform in shape, and white within. The outer lip is thin and sharp, areuate or straightened; basal margin arcuate. Columella concare. Columellar and parietal margins are covered with $a$ rers heary white callus, which is thickened into a low nodule or pad near the posterior angle of the aperture.

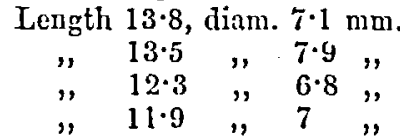

The operculum is rounded-orate, smaller and especially shorter than the aperture.

Hab.-Cos River, a tributary of the Panuco, State of San Luis Potosi, Mexico.
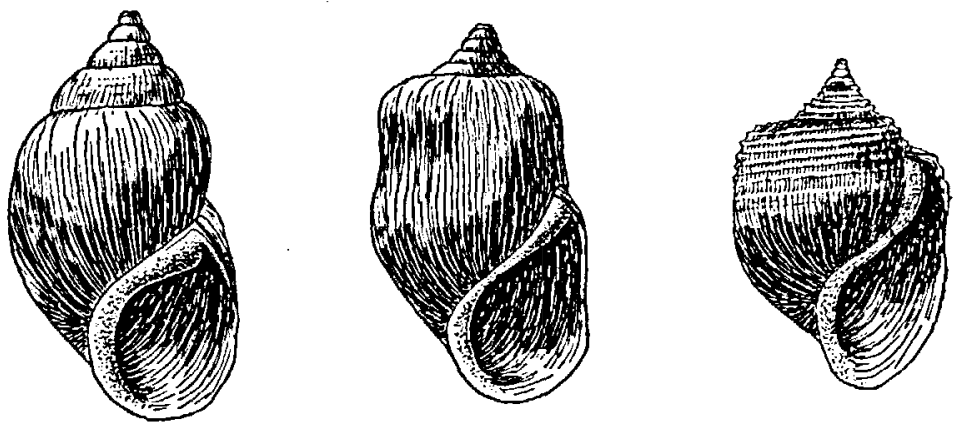

Fro. 3. Lithasiopsis Hinlileyi. Two adult and one young example.

This species has much in common with Lithasia obovata (Say). The general shape, colour, and columellar callus are similar; but the operculum differs ridely. The shape of shell and aperture are remarkably variable, but even in the more orate and lengthened examples, the last whorl is decidedly shouldered, unlike the following species. As in many Pleuroceratidx, smooth and spirally striate forms coexist in the same colonies.

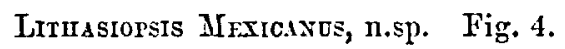

The shell is orate-turrite, with straightly conic spire; solid, lustreless, variously coloured; olive-yellow, uniform or with a blackish olive median band, or purplish black, paler below the suture. The first $2 \frac{1}{2}$ whorls are smooth and conrex, the following whorls flattened, at first smooth, but about the fifth whorl a fer spiral threads appear. These threads continue to the penultimate whorl, where they decrease, leaving the last whorl smooth; or they may persist as very weak angles on the last whorl. Whorls 9 or 10 in complete examples, but the earliest ones are generally worn or eroded in adult individuals. Last whorl convex. Aperture orate, livid white 
or dark inside; outer lip thin and acute, slightly sinuous, adrancing slightly below, retracting a little towards the columella and abore. Columella concave, broadly white-calloused. Parietal wall in adults corered with a rather thick white callus, hearier towards the posterior or upper angle.

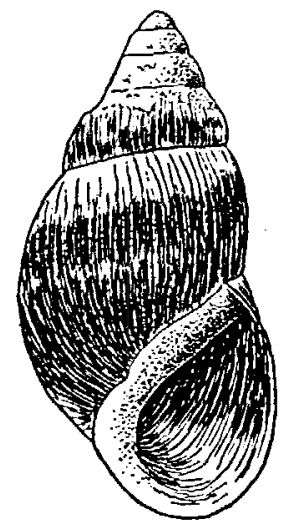

Frg. 4. Lithasiopsis Mexicanus, n.sp.

Length 16 ; diam. $8.2 \mathrm{~mm}$; aperture $7.8 \mathrm{~mm}$. long.

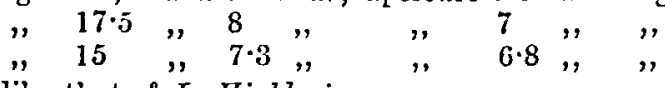

Operculum like that of $L$. Ininkleyi.

Mab.-Montezuma River, at the ford, a short distance above 'lampamolon, State of San Luis Potosi, Mexico.

This species has the appearance of a Goniobasis, but differs from that genus by its calloused columella. The dominant colour form is dull jellow, with one or sereral dusky bands on the last whorl and a bicoloured spire, each whorl light abore, dark below; but some examples are uniform 5ellowish or Jellowish brown, and very few (4 per cent. in the lot examined) are purplish or brownish black. 